\title{
The influence of design features of housing facilities on energy consumption
}

\author{
Sergei Kolodyazhniy ${ }^{1}$, Valeriy Mishchenko ${ }^{1}$, Elena Gorbaneva $^{1}$ and Kristina Sevryukova ${ }^{1,{ }^{*}}$ \\ ${ }^{1}$ Voronezh State Technical University, Moscow Avenue, 14, Voronezh, 394026, Russia
}

\begin{abstract}
This article analyzed the impact of the structural characteristics of old apartment buildings on actual energy consumption. The authors reviewed energy consumption in existing apartment buildings in Voronezh in order to determine the need for major repairs and energy efficiency. For this purpose, a comparative analysis of energy consumption in old apartment buildings and in new ones built in accordance with the current regulations was carried out. Three indicators of energy consumption were considered for analysis: total energy consumption by the end-user, heating of premises and electricity consumption depending on the year of construction of apartment buildings. The characteristics considered were used to quantify energy consumption (heating and power supply). Due to the results obtained, a statistical analysis of energy consumption in old apartment buildings and in new ones was carried out. It was noted that old apartment buildings consume more energy than those built at a late stage, in accordance with the current regulatory framework. The results can be useful in identifying priority elements of the building that will help to effectively reduce energy consumption during major repairs and classify existing residential buildings to build energy models.
\end{abstract}

\section{Introduction}

Today, multi-story residential buildings are among the most dominant housing types worldwide. Emergency housing fund in the Russian Federation is growing rapidly every year, which is an actual problem.

According to the Ministry of Natural Resources, the Russian Federation ranks 4th in the world in terms of carbon dioxide emissions [1]. To solve this problem, measures are being taken to reduce Greenhouse gas emissions by improving and adjusting the regulatory framework and upgrading old dilapidated housing. This is due to the fact that old residential buildings do not meet energy-efficient requirements and were built in accordance with outdated building standards. So, from October 1, 2003, instead of the outdates SNiP II-3-79 "Thermal Protection of Buildings" was put into effect a new SNiP II-3-79 "Construction Heat Engineering". These standards provided for the introduction of new energy efficiency indicators in the design, construction and operation of buildings. Despite the introduction of new building codes, energy consumption in residential buildings has not decreased and $\mathrm{CO} 2$ emissions have not decreased.

\footnotetext{
* Corresponding author: ksevrukova@vgasu.vrn.ru
} 
Despite the efforts of the Government and the proposed technologies for energy conservation, there are restrictions in the creation of energy-efficient measures carried out during the reconstruction of old apartment buildings to reduce energy consumption, namely [2-6]:

1. Particular attention is paid to economic profits rather than energy efficiency or reducing $\mathrm{CO} 2$ emissions.

2. The existing regulatory framework using energy-efficient technologies does not sufficiently cover old apartment buildings in need of major repairs.

During various periods of time, the structural features of old apartment buildings were repeatedly changed during major repairs, which referred to outdated normative documents. Thus, the existing regulatory framework does not take into account the transformation of the characteristics of old apartment buildings.

This article suggested that changes in the characteristics of buildings, as a result of previous major repairs or renovations, affect energy consumption, these changes can be used in planning of activities for major repairs.

\section{Materials and Methods}

Considering the construction fund of the city of Voronezh, it can be noted that the largest share of all types of buildings are apartment buildings [7,8]. Most of these buildings were built in the 20th century. The average wear percentage of apartment buildings can be seen in Figure 1 (Source: https://dom.gosuslugi.ru). Based on the material studied [9], it can be noted that old apartment buildings built more than 20 years ago are not energy efficient.

The main goal in the construction of the first apartment buildings in Voronezh was to accommodate a rapidly growing urban population. Thus, between the 1930s and 1950s, the first mass construction of apartment buildings began. They were built during the reign of I.V. Stalin, so in the simple family they were called "Stalin's." The main material in the construction of such houses was brick. During this period, low-rise apartment buildings of corridor type - communes and dormitories - were mainly built [10].

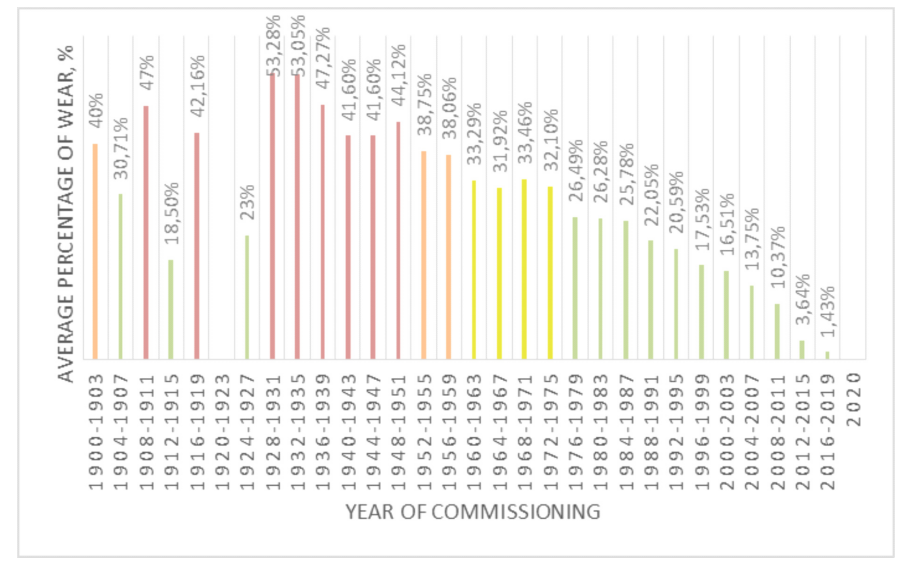

Fig. 1. The average wear percentage of apartment buildings by year of commissioning in Voronezh.

Actively built low-rise economy-class houses in the USSR began after the adoption of the resolution "On the development of housing construction in the USSR" of July 31, 1957. This document laid the foundation for a new housing construction - the house of the "Khrushchev" building. 
These apartment houses were called "Khrushchev." They had typical layouts and were built between 1958 and 1985. Material of bearing structures: panel or brick. Such houses were mid-rise and small-sized. Such frame houses were built in record time. As a result, convenience suffered for the sake of economy, but the problem with housing shortage was solved [11].

By 1966 , more than $90 \%$ of residential buildings and $76 \%$ of public structures in Voronezh were built according to model projects.

In the 1970s, "Khrushchevs" were replaced by "brezhnevka." Most of them were built from prefabricated concrete panels. There were houses from 8 to 16 floors with elevators and garbage disposal.

Houses of improved layout began to be built in the 1980s. Their main advantage is the large areas of rooms and kitchens and good comfortable layouts without passable rooms.

In the early $2000 \mathrm{~s}$, the average size of apartments in new apartment buildings was a maximum of $69 \mathrm{~m} 2$, over the past years the average area of apartments has decreased to 56 $\mathrm{m} 2$.

Economic profit is also a significant factor for transforming building features in existing apartment buildings. There are four schemes of planning of buildings: sectional, corridor, gallery and centric [12].

The corridor scheme is corridors inside the apartment building, along which there are apartments with one-sided orientation of windows. Such houses necessarily have two exits through two staircases, between which apartments are located. Such a scheme is considered the most economical, because it allows to place within the specified area the maximum number of apartments.

The gallery scheme is a kind of corridor layout scheme. In houses with a gallery scheme the entrance to the apartment is arranged with floor open galleries, and all apartments have double-sided orientation of windows and through ventilation. Such houses necessarily have two exits. Compared to the corridor gallery scheme is considered less economical, as it allows to place a smaller number of apartments within the given area.

In the practice of housing construction, the most common multi-story residential buildings with a sectional planning scheme. The planning difference between the sections of residential buildings is the organization of the staircase assembly and the number of elevators. The layout of the section in the plan does not have any certain limitations. The locking of various sections provides of the opportunity to design residential buildings of various shape and size. However, in modern urban planning a more complicated form of multi-storey residential buildings used, the planning solution of which allows to obtain a variety of plans of apartments with improved conditions of insolation and ventilation. The planning structure of sections with complicated perimeter has a number of functional advantages and allows more fully to implement artistic design. In buildings with a height of less than three floors, the use of a sectional layout scheme is not economically feasible.

The centric scheme consists of a large central room around which small living spaces are grouped. The centric layout scheme is compact and optimal for point high-rise buildings.

Some features of apartment buildings have been transformed due to the introduction of new regulatory documents and the development of construction technologies. Initially, the thermal regime of fencing structures in existing apartment buildings were determined in 1954 with the implementation of the first building norms and regulations.

As a consequence of the first global energy crisis in 1979, instead of the old buildings norms, was released SNiP II-3-79 "Construction Heat Engineering". Thanks to this regulatory document, for the first time the level of thermal protection of buildings is taken into account and the transition to multi-layer walling with thermal insulation. Despite the 
high growth in housing construction until 2003, there was no review of building norms and regulations aimed at improving the thermal conditions of buildings.

Three main system can be identified in old apartment building when considering the heat supply system [13]: centralized heat supply systems, decentralized heat supply systems and individual decentralized heat supply systems.

The final introduction of central heating of apartment buildings in Voronezh occurred with the beginning of mass housing construction of "Krushchev". Along with the connection of houses to thermal power station and boiler plants, district boiler houses were built in new residential areas [14].

Studying the housing fund of Voronezh, we conditionally divided it into "old apartment buildings," built before 2003 and "new apartment buildings," built after 2003 (in connection with the introduction of SNiP 23-02-03 "Thermal protection of buildings" since 2003).

Table 1. Comparing Building Design Characteristics.

\begin{tabular}{|c|c|c|c|c|c|c|c|}
\hline \multirow[b]{2}{*}{$\begin{array}{c}\text { Apartment } \\
\text { Characteristic }\end{array}$} & \multicolumn{6}{|c|}{$\begin{array}{c}\text { Building Regulations / } \\
\text { Validity } \\
\end{array}$} & \\
\hline & & 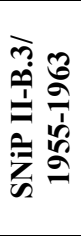 & 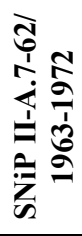 & 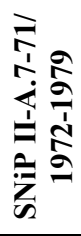 & 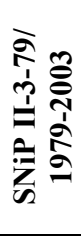 & 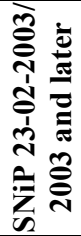 & \\
\hline \multirow{3}{*}{ Heating system } & + & + & + & + & + & + & centralized \\
\hline & - & - & - & + & + & + & decentralized \\
\hline & - & - & - & - & + & + & $\begin{array}{c}\text { individual } \\
\text { decentralized }\end{array}$ \\
\hline \multirow{3}{*}{$\begin{array}{l}\text { Material of } \\
\text { structural walls }\end{array}$} & + & + & + & - & - & - & brick \\
\hline & - & + & + & + & + & + & panel \\
\hline & - & - & - & - & + & + & monolith \\
\hline \multirow{3}{*}{ Storeys } & + & + & - & - & - & - & $\begin{array}{l}\text { low rise } \\
(1-2 \text { fl. })\end{array}$ \\
\hline & - & + & + & + & - & - & $\begin{array}{l}\text { mid-rise } \\
(3-5 \text { fl. })\end{array}$ \\
\hline & - & - & - & + & + & + & $\begin{array}{l}\text { multi-storey } \\
\text { ( } \geq 6 \text { fl.) }\end{array}$ \\
\hline \multirow{4}{*}{ Building Plan } & + & + & - & - & - & - & bellboy \\
\hline & - & - & - & - & - & - & gallery \\
\hline & - & - & + & + & + & + & sectional \\
\hline & - & - & - & - & + & + & centric \\
\hline
\end{tabular}

By analyzing the previous regulatory documents and studying the history of domestic house construction [13 - 15], the distinctive characteristics of "old apartment buildings" have been revealed since the 1930 s.

As noted above, with the change of public preference, the following characteristics of multi- apartment buildings were transformed: number of floors, structural material and layout scheme. It is also worth noting the change in the area of multi-apartment buildings depending on the layout plan. 
One of the reasons for changing the characteristics of apartment buildings is also the improvement of building standards and technologies.

On the basis of this, the thermal conditions of fencing structures of buildings were measured by years of construction which were separated by a revision of the construction norms and rules: to 1955, 1955 - 1963, 1963-1972, 1972-1979, 1979 - 2003 and after 2003. In addition, three types of heating system were considered.

In view of these transformations, apartment buildings with different characteristics were considered to identify the actual characteristics affecting energy consumption. Table 1 shows how the structural features of buildings have changed.

\section{Results}

The ratio of considered characteristics is necessary for quantitative assessment of energy consumption (heating and electricity supply). Based on the data obtained, a statistical analysis of energy consumption in old apartment buildings and new ones was carried out.

- "Old apartment buildings" built before 2003.

For analysis, 18 old apartment buildings were selected. Four parameters were taken into account for the selection of residential buildings: year of construction; number of floors; availability of data on energy consumption, structural material. We considered apartment houses that were built between 1946 and 1983 .

Information on energy consumption was taken into account for 2016 and was obtained from open sources (https://www.reformagkh.ru). The collected data for electricity and heating were transformed in $\mathrm{kWh}$ per square metre per year.

The buildings that were built after 2003 were selected to compare energy consumption in older apartment buildings because they are considered relatively energy efficient. Data on electricity and thermal energy consumption were collected by the same method as for old apartment buildings.

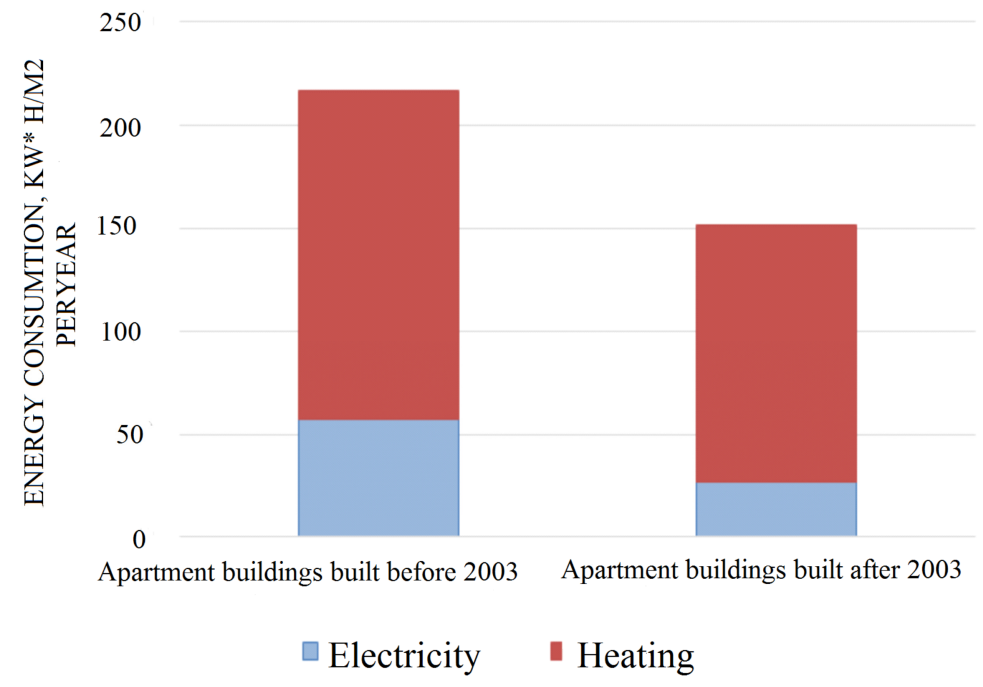

Fig. 2. Average energy consumption in selected apartment buildings (by years of construction).

In fig. 2 shows the average comparison of energy consumption in old apartment houses which is at $212 \mathrm{kWh}$ per square meter per year and $152 \mathrm{kWh}$ per square meter per year in new houses, respectively. This result shows the influence of design features on the energy consumption of both groups of apartment buildings. 
These changes are also shown in Figures 4 and 5. The average energy consumption during heating of apartments in old apartment buildings is higher than in new ones. The energy used in the old apartment houses built before the 80th years exceed average of 186 $\mathrm{kWh} / \mathrm{m} 2$ per year. None of the buildings built between 2003 and 2015 consumed more than average for heating. These results show that apartment buildings built after 2003 were able to effectively reduce energy consumption for heating.

Electricity consumption also declined during the period under review. This can be explained by the use of modern household appliances, which consume significantly less electricity than their ten-years-old predecessors. In general, apartment buildings have been able to effectively reduce energy consumption with regard to heating and electricity.

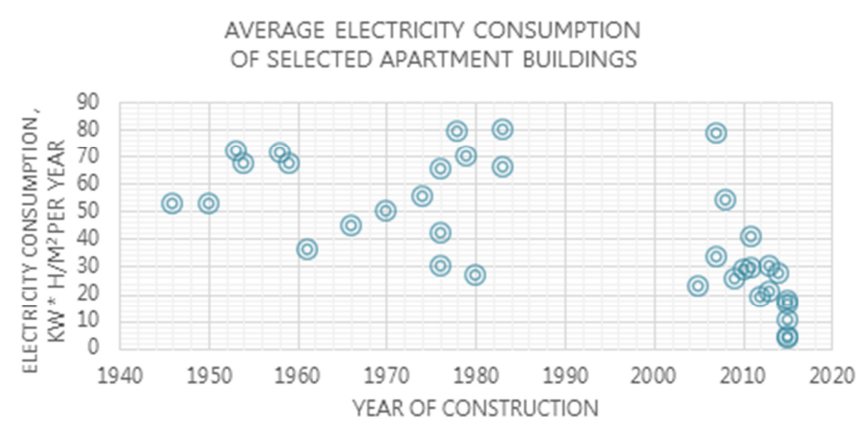

Fig. 3. Electricity consumption by apartment buildings by years of construction.

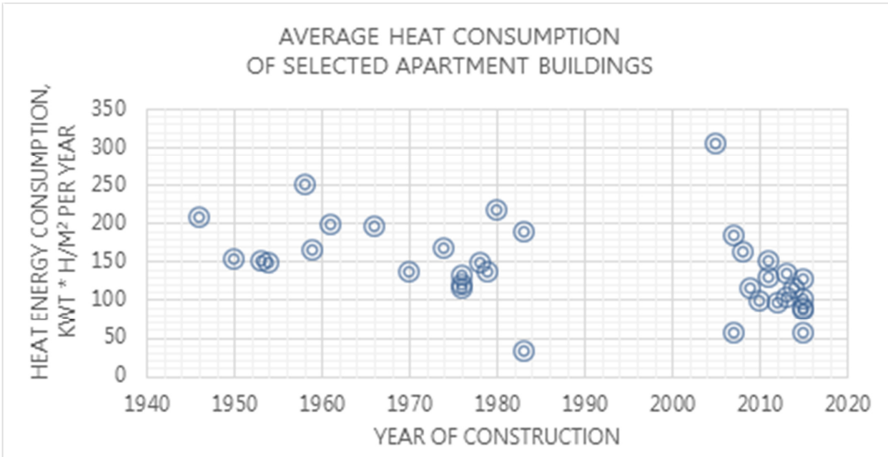

Fig. 4. Heat energy consumption by apartment buildings by years of construction.

\section{Conclusions}

As expected, older apartment buildings built at an early stage consume more energy than those built at a late stage. Three conditions: enclosing structures of buildings, heat supply system and total area of residential premises are more influenced and explain this growing trend of energy consumption. This means that the conversation of these design features will reduce energy consumption to greater extent.

The noted design features of residential buildings allow to select the most energyefficient list of measures during major repairs and their sequence:

- increase of thermal resistance of enclosing structures due to: glazing of balconies and lodges, elimination of cold bridges in walls and in connections of window binding, heat 
insulation of external walls, technical floor, roof, floors above the basement with modern energy-efficient materials, etc.;

- increase of energy efficiency of heating system due to: additional heating and heating of water when using solar collectors and heat accumulators, installation of thermostats and temperature regulators on radiators, transition during repair to the scheme of individual apartment heating, etc.;

- energy savings due to: use of energy-efficient household appliances of class $\mathrm{A}+$ and $\mathrm{A}++$, commissioning of solar panels and systems with installation of motion sensors during maintenance of common property, etc.

The application of the proposed approach in reconstruction and major repairs can lead to an increase in the energy efficiency of apartment buildings. Thus, reconstruction activities should take into account the specific features of apartment buildings in order to use more effective reconstruction strategies and rules. In order to work more effectively in the proposed approach and to assess the condition of the housing stock more accurately, it is necessary to use modeling of changes in the life cycle of apartment buildings under various operating conditions.

\section{References}

1. N.V. Gusakova, K.E. Filyushina et al., Magazine of Civil Engineering 7(75), 84-93 (2017) DOI: 10.18720/MCE.75.8

2. V.Ya. Mishchenko, S.G. Sheina et al., IOP Conf. Series: Materials Science and Engineering 481, 012031 (2019) DOI: 10.1088/1757-899X/481/1/012031

3. V. Mishchenko, E. Gorbaneva et al., Advances in Intelligent Systems and Computing 983, 79-9 (2019). DOI: 10.1007/978-3-030-19868-8_8

4. N. Vatin, A. Gorshkov, D. Nemova, D. Tarasova, Applied Mechanics and Materials 633-634, 991-996 (2014) DOI: 10.4028/www.scientific.net/AMM.633-634.991

5. T. Saknite, D. Serdjuks, V. Goremikins, L. Pakrastins, N.I. Vatin, Magazine of Civil Engineering 64(4), 26-39 (2016) DOI:10.5862/MCE.64.3

6. V.A. Rybakov, K.G. Kozinetc, N.I. Vatin, V.Z. Velichkin, V.I. Korsun, Magazine of Civil Engineering 82(6), 103-111 (2018) DOI:10.18720/MCE.82.10

7. Z. Radovanović, R. Sindić, S. Dimovska, N. Serdar, N. Vatin, V. Murgul, Procedia Engineering 117(1), 865-873 (2015) DOI:10.1016/j.proeng.2015.08.155

8. I.N. Priadko, V.P. Mushchanov, H. Bartolo, N.I. Vatin, I.N. Rudnieva, Magazine of Civil Engineering 65(5), 27-41 (2016) DOI:10.5862/MCE.65.3

9. A. Ponomarev, M. Knezević, N. Vatin, S. Kiski, I. Ageev, Journal of Applied Engineering Science 12(3), 227-231 (2014) DOI:10.5937/jaes12-6161

10. M. Penić, N. Vatin, V. Murgul, Applied Mechanics and Materials 680, 534-538 (2014) DOI:10.4028/www.scientific.net/AMM.680.534

11. T.V. Nazmeeva, N.I. Vatin, Magazine of Civil Engineering 62(2), 92-101 (2016) DOI:10.5862/MCE.62.9

12. B. Kovačič, R. Kamnik, V. Solovev, N. Vatin, Procedia Engineering 165, 926-935 (2016) DOI:10.1016/j.proeng.2016.11.802

13. B. Kovačič, R. Kamnik, A. Pustovgar, N. Vatin, Procedia Engineering 165, 906-917 (2016) DOI:10.1016/j.proeng.2016.11.800

14. S.V. Korniyenko, N.I. Vatin, A.S. Gorshkov, Magazine of Civil Engineering 64(4), 10-25 (2016) DOI:10.5862/MCE.64.2 
15. Z. Jakšic, D. Ladjinović, M. Trivunić, N. Harmati, N. Vatin, Procedia Engineering 117(1), 502-515 (2015) DOI:10.1016/j.proeng.2015.08.252 